\title{
Pengaruh Pembelajaran E-Learning Terhadap Mutu Belajar Dengan Mutu Proses Belajar Mengajar Sebagai Variabel Intervening Mata Kuliah Perbankan Syariah
}

\author{
Danya Radinda Suprayogie ${ }^{1}$, Luqman Hakim ${ }^{2}$ \\ Universitas Negeri Surabaya \\ danya.17080304024@mhs.unesa.ac.id¹, $\underline{\text { luqmanhakim@unesa.ac.id² }}{ }^{2}$
}

\begin{abstract}
Abstrak: Dalam menghadapi new normal, dunia pendidikan juga memiliki pembaruan dibidang akademik. Yaitu pembelajaran melalui system elektronik atau daring. Meskipun begitu pendidik dituntut untuk tetap mampu mencapai tujuan pembelajaran. Penelitian ini bertujuan untuk menganalisis pengaruh pembelajaran e-learning berbasis zoom meeting melalui kualitas proses belajar mengajar terhadap mutu belajar mahasiswa. Metode penelitian yang digunakan dalam penulisan ini adalah kuantitatif, dengan objek penelitian mahasiswa program studi pendidikan akuntansi universitas negeri surabaya yang berjumlah 62 mahasiswa serta menggunakan teknik porrposive sampling, dengan kriteria mahasiswa yang melaksanakan proses pembelajaran perbankan syariah melalui e-learning. Hasil penelitian menunjukkan bahwa terdapat pengaruh positif dari variabel e-learning berbasis zoom meeting terhadap mutu belajar mahasiswa. Dan pada hasil penelitian variabel pembelajaran e-learning berbasis zoom meeting terhadap proses belajar mengajar juga berpengaruh positif. Kesimpulan dari pengolahan data statistik tersebut dapat dinyatakan apabila pembelajaran $e$ learning berbasis zoom meeting ini dapat berpengaruh secara langsung dengan angka yang signifikan pada mutu belajar mahasiswa Pendidikan Akuntansi angkatan 2018. Hasil dari penelitian ini juga dapat dijadikan bahan acuan untuk mengembangkan media pembelajaran berbasis e-learning.
\end{abstract}

Kata Kunci : E-Learning; Mutu Belajar; Mutu Proses Belajar Mengajar.

Abstract: In facing the new normal, the world of education also has reforms in the academic field. Namely learning through an electronic system or online. Even so, educators are required to be able to achieve learning goals. This study aims to analyze the effect of the quality of learning through e-learning learning based on zoom meetings and the quality of the teaching and learning process which is an intervening variable. The research method used in this writing is quantitative, with the object of research being 62 students of the accounting education study program at the State University of Surabaya who are spread out from 2 different classes. Implementing the Islamic banking learning process through e-learning. The results showed that there was a positive effect of a number of e-learning variables based on zoom meetings on the quality of learning. And for the research results, the e-learning learning variables based on zoom meetings on the quality of the teaching and learning process also have a positive effect. So that in this research, the statistical test of e-learning learning based on zoom meetings by means of the quality of the teaching and learning process has an effect on the learning quality of the 2018 batch of Accounting Education students.

Keywords:E-Learning; Learning Quality; Online Learning 


\section{Pendahuluan}

Awal tahun 2020 dunia sedang gempar dengan suatu wabah baru yang berasal dari china, tiongkok. Wabah corona virus disease (covid-19) telah menularkan hingga seluruh belahan dunia tepatnya telah menjalar lebih dari 200 negara. Cepatnya menularan wabah virus baru ini berdampak pada kegelisahan banyak negara terutama pada rakyatnya. Wabah virus corona disease ini menimbulkan tantangan baru dalam berbagai aspek kehidupan. Salah satunya dibidang pendidikan, yang dikhususkan pada pendidikan perguruan tinggi. Banyak antisipasi yang dilakukan negara dalam meminimalisir penyebaran virus ini,contohnya seperti isolasi mandiri, sosial and physical distancing sampai pada upaya membatasi kerumunan berskala besar. Hal demikian juga menguras tenaga dan otak para pendidik dalam melakukan proses pembelajaran. Penerapan yang berfungsi sangat adaptif dengan masa pandemi ini adalah pembelajaran melalui e-learning. Pembelajaaran e-learning adalah model baru yang dalam penyampaian informasi dan materi kepada peserta didik melalui perangkat lunak. Peserta didik juga diwajibkan untuk mengakses aplikasi menunjang pembelajaran seperti zoom, google meet, classroom dan sebagainya. Salah satu yang penggunaan nya melonjak signifikan adalah aplikasi zoom meeting dengan berbagai fitur yang ditawarkan, salah satunya menampilkan file presentasi yang bisa dikirim pada semua anggota rapat serta mereka akan mendapatkan notifikasi ketika file berhasil terkirim.

Selanjutnya terdapat beberapa penyebutan indikator dari sistem pembelajaran e-learning menurut (Koran, 2015) ialah yang (1)Materi belajar dan soal evaluasi,dalam melengkapi bahan belajar ini bisa didapati pada modul yang dilengkapi dengan soal latian atau evaluasi. (2)Komunitas, mahasiswa mampu membentuk dan meluaskan komunitas online untuk saling membantu dalam menyebarkan informasi. (3)Dosen online, tugas dosen dalam melengkapi pembelajaran e-learning ini ialah untuk memberikan motivasi untuk mengarahkan mahasiswa pada saat dilakukannya pembelajaran e-learning ini, serta memberikan penjelasan, menjawab pertanyaan dan membantu jalannya diskusi dalam kelas online. (4)Kesempatan bekerjasama, media elektronik dapat mengefektifkan jalannya pembelajaran dalam kelas online yang dapat diatur secara fleksibel. (5)Multimedia, dengan fitur audio dan visual atau video pada saat penyampaian materi belajar sehingga akan menarik mahasiswa untuk lebih interaktif dalam menjalankan proses belajar secara e-learning.

Seperti penelitian yang berjudul "Pemanfaatan Zoom Meeting untuk proses pembelajaran pada masa pandemi covid 19" yang dilakukan oleh (Haqien \& Rahman, 2020) menyatakan bahwa aplikasi zoom meeting ini adalah salah satu media yang cocok digunakan pada masa Sosial Distancing. Namun tidak bisa dijadikan bahan utama dalam mengukur kesuksesan pembelajaran. Karena media pembelajaran melalui Zoom Meeting bisa mengalami kendala dari sistem jaringan atau sinyal internet. Hal ini akan mempengaruhi kualitas dan mutu belajar yang diterima oleh mahasiswa.

Belajar dapat dimaknai sebagai perubahan perilaku yang dialami setiap indvidu secara keseluruhan. Dan mampu memiliki fungsi serta berperan sebagai pendorong untuk membantu meningkatkan prestasi dalam pembelajaran. yang sesuai dengan tujuan pelaksanaan proses pembelajaran (Daniati et al., 2020). Menurut (Subhi, 2020) dalam berbagai kondisi yang tidak dapat diprediksi, pendidikan wajib untuk tetap harus berjalan. Dari sini dapat disimpulkan bahwa keberhasilan pencapaian pembelajaran dapat diukur melalui cara seseorang dalam melaksanakan proses belajar yang sesuai dengan tujuan pembelajaran yang telah disusun sehingga dapat melaksanakan dan merealisasikan dengan profesionalistas. Didalam kegiatan belajar mengajar yang bermutu itu tergantung pada kemampuan dosen 
yang dibantu mahasiswa untuk mengaplikasikan dalam menggunaan semua komponen yang bisa mendukung pencapaian tujuan belajar sehingga dapat mengoptimalkan mutu belajar (Subhi, 2020) Menurut Bloom, dkk. Dalam (Dimyati \& Mudjiono, 2006) ada beberapa indikator sebagai pengukur mutu belajar yaitu: 1)Pengetahuan (Knowledge),2)Pemahaman (Comprehension),3)Penerapan,(Aplication),4)Analisis(Analysis),5)Sintesis(Synthesis),6)Eval uasi (Evaluation). Dalam penelitian terdahulu yang berjudul " Pengaruh Pembelajaran Elektronik (E-Learning) Terhadap Mutu Belajar Mahasiswa oleh (Karwati, 2014) yang menyimpulakan bahwa $E$ - learning memiliki pengaruh yang sinifikan pada kualitas mutu dalam belajar para mahasiswa FKIP UNINUS Bandung. Adapun penelitian terdahulu yang dilakukan (Suharyanto \& Mailangkay, 2016) Yang berjudul "Penerapan E-learning Sebagai Alat Bantu Mengajar dalam Dunia Pendidikan" yang menuliskan kesimpulannya bahwa pembelajaran berbasis e-learning ini berpengaruh positif terhadap mutu belajar siswa. Dan pemanfaatan e-learning dapat menunjang hasil belajar secara optimal.

Mutu hasil proses belajar mengajar ialah ukuran dari suatu kualitas yang dapat mencerminkan mutu dari kegiatan belajar yang dihasilkan oleh mahasiswa dan guru (Subhi, 2020). Menurut (MARINI, 2017) keberhasilan alam proses akademik ditentukan melalui hasil belahar dan karakter baik. Karakter ini dapat diintegrasikan kedalam kegiatan aktifitas belajar didalam kelas. Proses belajar mengajar ini nantinya akan mempengaruhi hasil akhir dari kualitas belajar anak, karena itu perlu ditanamkan sejak awal pembelajaran agar mahasiswa dapat membiasakan memiliki perilaku belajar yang baik. Proses belajar mengajar ini bisa diaplikasikan kepada mahasiswa dalam bentuk aktifitas analisis, eksplorasi, evalusi hingga konfrimasi. Terdapat 3 Indikator yang ada pada kegiatan belajar yakni, pertama, proses belajar mengajar yang dipusatkan kepada siswa, kedua, proses belajar mengajar partisipasi demokratis, dan yang ketiga yaitu proses belajar mengajar yang inklusif (Suhirman, 2012) Dari hasil jurnal relevan yang ditulis oleh (McCombs, 2000) yang memiliki kesimpulan bahwa mutu proses belajar mengajar juga memiliki bagian terpenting untuk berkontribusi dalam meningkatkan mutu belajar pula Dalam penelitian (Sumardi et al., 2020) ini menyatakan bahwa proses belajar mengajar yang cocok untuk diterapkan dalam pembelajaran abad 21 ini yaitu yang memiliki penerapan model dan metode belajar yang sesuai, peran aktif TIK sebagai media pembelajaran, dan kelengkapan dalam materi.

Berdasarkan latar belakang dan uraian masalah yang didapat dari fenomena yang pada saat ini terjadi, tujuan penelitian ini adalah untuk menganalisis hasil mutu belajar mahasiswa melalui proses belajar mengajar yang berbasis e-learning. Penelitian ini dilakukan diharapkan dapat memberikan manfaat. Dalam penelitian ini banyak sekali mengkonfrimasi dari teori yang sudah ada yang berhubungan dengan pembelajaran online atau daring serta kualitas didalam proses serta hasil pembelajaran. Selain itu penelitian ini bermanfaat untuk memberikan sebuah evaluasi dan pengetahuan baru berupa informasi yang dapat digunakan sebagai acuan pengambilan sebuah kebijakan yang berkaitan dengan realisasi pembelajaran daring sebagai cara meningkatkan kualitas mahasiswa dalam mengikuti pembelajaran di lingkungan kampus Fakultas Ekonomi Universitas Negeri Surabaya.

\section{Metode Penelitian}

Metode didalam penelitian ini menggunakan metode penenlitian kuantitatif. Menurut (Suliyanto, 2017) penenlitian kuantitatif ialah penelitian empiris dengan penggunaan sumber data yang valid dan jelas. Dalam menentukan ukuran data metode penelitian kuantitatif ini bisa menggunakan jawaban sementara dari hasil pernyatan penelitian. Dan menjadikan 
sampel sebagai alat genelisasi hasil populasi. Sehubung dengan latar belakang fenomena yang ada dan pendahuluan tersebut sehingga peneliti menggunakan penelitian berjenis kuantitatif. Pendekatan kuantitatif ini merupakan penenlitian ilmiah yang bisa dikumpulkan melalui instrumen yang sangat reliable dan akurat melalui alat statistik dan analisis. Adapun rancangan penelitiannya dapat dilihat pada Ganbar 1:

\section{Gambar 1. Kerangka Konseptual}

\section{H1}

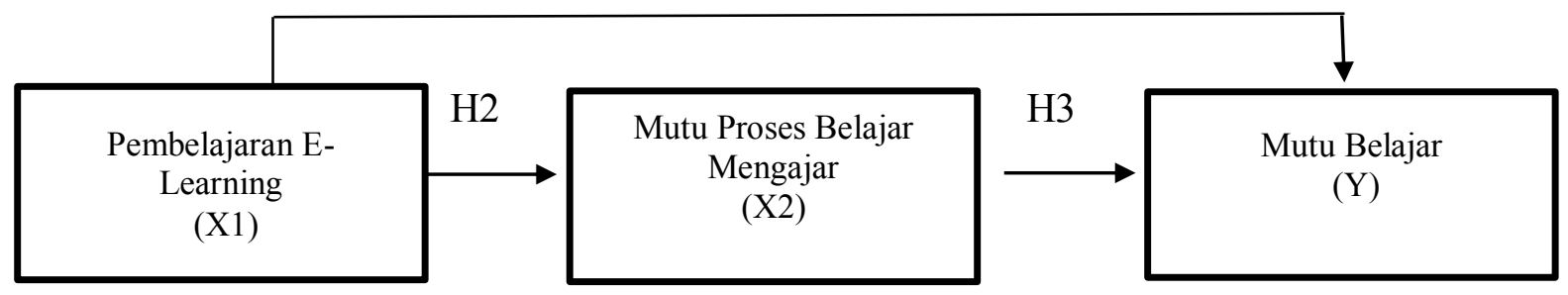

Sumber: Diolah peneliti (2021)

Populasi yang akan dituju dalam penelitian ini merupakan mahasiswa aktif Universitas Negeri Surabaya Angkatan 2018 yang sedang menempuh mata kuliah pada semester 5. Dalam mencari sampel yang sesuai penelitian ini menggunakan teknik pupossive sampling. Didalam penggunaan teknik ini, terdapat beberapa kriteria yang telah ditetapkan oleh peneliti untuk medukung kevalidan penelitian. adapun kriteria yang telah dipertimbangkan dalam menentukan sampel yaitu mahasiswa program studi pendidikan akuntansi yang menjalani mata kuliah perbankan syariah secara daring. Dari kriteria yang telah ditetapkan maka sampel yang sesuai adalah mahasiswa program studi pendidikan akuntansi angkatan 2018 yang berjumlah 62 orang mahasiswa. Didalam penelitian ini peneliti menggunakan teknik pengumpulan data melalui instrumen kuisioner. Kuisioner ialah suatu jenis teknik yang difungsikan untuk mengambilan data dengan cara menyuguhkan beberapa butir pertanyaan yang harus dijawab oleh responden sebagai sampel penelitian. Dalam kuisioner ini digunakan skala likert dalam memperoleh sumber data yang valid pada setiap variabel pembelajaran $e$ learning, mutu belajar dan mutu proses belajar mengajar. Angket ini akan disebarkan kepada mahasiswa aktif Universitas Negeri Surabaya yang sedang menjalankan mata kuliah perbankan syariah disemester 5 melalui google form. Pengelolaan data serta analisis data penelitian melalui alat-alat uji statsitik yang valid dan relevan yang bisa membantu menyelesaikan tujuan penelitian. Sedangkan alat analisis data yang akan dgunakan didalam peneleitian ini adalah dengan uji kualitas data yaitu melalui uji validitas dan reabilitas serta alat analisis data berupa regresi linier berganda dan uji efek mediasi (metode analisis jalur(path analysis) yang dapat dikekola melalui program SPSS.

\section{Hasil dan Pembahasan}

\subsection{Uji Validitas}

Dari perolehan pengelolaan data validitas maka diketahui untuk seluruh item yang berjumlah 40 penyataan variabel $\mathrm{X} 1, \mathrm{X} 2$ dan $\mathrm{Y}$ dinyatakan valid. Hal ini artinya bahwa 40 pertanyaan secara keseluruhan mampu untuk mengukur pengaruh pembelajaran $E$ - 
learning berbasis Zoom Meeting, mutu belajar dan mutu proses belajar mengajar. Keseluruhan item yang valid ini karena besarnya korelasi item dibandingkan dengan skor total lebih besar yaitu berada pada angka 0,2500

\subsection{Uji Reabilitas}

Reliabilitas merupakan indeks untuk mengetahui seberapa jauh alat ukuran dapat dipercaya serta diandalkan. Yang memiliki ketentuan angka cronbach alpha $>0,60$, sehingga dapat dinyatakan alat atau instrumen tersebut reliabel. Dari hasil pengolahan data dapat disimpulkan bahwasannya instrumen kuisioner penelitian ini bersifat reliabel, hal ini disebabkan karena koefisien Cronbach's Alpha variebl pembelajaran E-learning, Mutu belajar dan mutu proses belajar mengajar berada diangka lebih besar dari 0,60. Yang artinya dari hasil uji coba instrumen penelitian ini dinyatakan valid serta reliabel dari keseluruhan item pertanyaan, dari pernyatan variabel pembelajaran elearning yaitu 15 soal, pernyataan mutu belajar yaitu 16 soal, dan pernyatan mutu proses belajar mengajar yaitu 9 soal. Item dari masing-masing instrumen ini dapat dikatakan berfungsi dalam mengukur hasil pengumpulan data. Adapun pengelolaan hasil data pengujian reliabilitas Mutu Belajar dapat dianalisis pada tabel pengolahan hasil data melalui SPSS Versi 18. Dari uji data reliabilitas tersebut disimpulkan bahwa angka cronbach's Alpha sebesar 0,825 dan dinyatakan reliabel karena cronbach alpha $>0,6$ ( Sugiyono, 2011). Yang secara demikian instrumen kuisioner variabel mutu belajar dari penelitian ini bersifat reliabel. Dan hasil dari pengolahan instrumen Mutu proses belajar mengajar menunjukkan hasil berdasarkan angka cronbach's alpha >0,60 yaitu 0,716 sehingga dapat dikatakan handal atau reliabel. Dari keseluruhan soal pada instrumen mutu proses belajar mengajar sebanyak 9 item, semuanya reliabel.

\subsection{Uji Analisis Jalur ( Path Analysis )}

Dalam analisis jalur ini berfungsi untuk menjelaskan gambaran dalam alat uji coba suatu hubungan yang berasal dari beberapa variabel yang menciptakan sebab akibat (Imam, 2013)

\section{Uji Hipotesis}

\section{a. Pengujian Substruktural 1}

Fungsi dalam uji ini sebagai alat mengetahui pengaruh variabel pembelajaran elearning terhadap mutu belajar. Dan dapat dianalisis melalui Rumus : X2 = px2X1+e1 angka konstan yang berada pada angka 21.723 ini menyimpulkan jika tidak terdapat nilai yang naik yang berasal dari variabel pembelajaran e-learning (X1) maka besarnya mutu proses belajar mengajar (X2)yaitu sebesar 21.723. sehingga memiliki koefisien jalur pada angka 0,653 yang bermakna bahwa setiap nilai pembelajaran e-learning naik sebesar $1 \%$ berarti mutu belajar juga dapat naik secara bersamaan sebesar 0,653 .

\section{1) Pengaruh pembelajaran e-learning terhadap mutu belajar}

$\mathrm{H} 1$ : adanya pengaruh secara langsung yang signifikan terhadap pembelajaran e-learning dengan mutu belajar

Dari analisis hipotesis tersebut maka ingin diuji untuk mengetahui pengaruh langsung dari pembelajaran e-learning dengan mutu belajar. Yang telah digambarkan pada tabel 
coefficients substruktural 1. Yang dapat dilihat bahwa angka signifikan berada pada angka 0,000 . Oleh karena itu nilai dari angka signifikan tersebut lebih kecil dari $0,05(0,000<$ $0,05)$ yang disimpulkan bahwa $\mathrm{H} 1$ positif. Atau bisa diterima, terdapat pengaruh secara langsung dengan sangat signifikan dari pembelajaran e-learning terhadap mutu belajar.

\section{b. Pengujian substruktural 2}

Hasil uji substruktural 2 ini diambil melalui pengolahan data yang brasal dari SPSS pertama yaitu variabel pembelajaran e-learning sebagai variabel bebas atau independen dan variabel mutu belajar sebagai variabel terikat. Uji ini berfungsi untuk mencari tahu sebesarapa berpengaruh antara variabel pembelajaran e-learning dan mutu belajar terhadap mutu proses belajar mengajar. Berikut adalah hasil tabel sub struktural 2. Malalui rumus : $\mathrm{Y}=\mathrm{pYx} 1 \mathrm{X} 1+\mathrm{Pyx} 2 \mathrm{x} 2+\mathrm{e} 2$. Berdasarkan olahan data diketahui konstan angka yaitu 9.157 yang berarti nilai dari variabel pembelajaran e-learning,dan mutu bealajar tidak memiliki kenaikan. Koefisien regresi pembelajaran e-learning yaitu 0,154, sehingga bisa disimpulkan apabila terdapat kenaikan dari variabel pembelajaran elearning sebesar $1 \%$, yang akan terjadi dari variabel lain yaitu mutu belajar juga akan mengalami kenaikan sebesar 0,154 dan untuk koefisien regresi mutu belajar 0,652 yang demikian apabila terdapat kenaikkan nilai pembelajara e-learning sebesar $1 \%$ yang akan terjadi pada variabel mutu belajar adalah ikut naik sejumlah 0,652.

\section{2) Pengaruh langsung pembelajaran e-learning terhadap mutu proses belajar mengajar}

$\mathrm{H} 2$ : adanya pengaruh secara langsung yang signifikan terhadap pembelajaran e-learning dengan mutu proses belajar mengajar

Hipotesis tersebut bertujuan untuk mengetahui apakah terdapat pengaruh secara langsung dari pembelajaran e-learning terhadap mutu proses belajar mengajar. Dari gamabaran tabel diatas diketahui nilai coefficient substruktural 2 dapat diperoleh nilai signifikan dari variabel pembelajaran e-learning ialah sebesar 0,037. Dari nilai signifikan dari variabel tersebut lebih rendah nilainya atau sama dengan 0,05 $(0,037>0,05)$ oleh karena itu disimpulkan bahwa $\mathrm{H} 2$ diterima. Yang secara demikian terdapat pengaruh secara langsung dengan nilai signifikan dari pembelajaran e-learning terhadap mutu proses belajar mengajar.

\section{3) Pengaruh langsung mutu belajar terhadap mutu proses belajar mengajar}

H3: adanya pengaruh secara langsung yang signifikan terhadap mutu belajar terhadap mutu proses belajar mengajar

Hipotesis tersbut bertujuan untuk mecari tahu dari pengaruh secara langsung dari mutu belajar terhadap mutu proses belajar mengajar. Dari tabel diatas dapat digambarkan nilai signifikannya adalah 0,000 . Yang berarti nilai tersebut lebih rendah atau sama dengan $0,05(0,000>0,05)$ maka H3 diterima, sehingga dapat disimpulkan bahwa adanya pengaruh secara langsung dengan nilai yang signifikan anatara mutu belajar terhadap mutu proses belajar mengajar. Melalui rumus $\mathrm{Y}=0,154 \mathrm{X} 1+0,652 \mathrm{X} 2+\mathrm{e} 2$ dari kedua gamabaran struktural yang ada dapat ditarik kesimpulan dari hipotsis yang berpengaruh 
secara tidak langsung yang berasal dari variabel pembelajaran e-learning (X1) terhadap mutu belajar (Y) melalui mutu proses belajar mengajar (X2)

Tabel 1. Penyajian data analisis jalur (path)

\begin{tabular}{lll} 
Variabel & Nilai Beta & Total \\
\hline X1 terhadap X2 & $0,653 \times 0,652$ & 0,4257 \\
X1 terhadap Y & $0,653 \times 0,152$ & 0,0992 \\
X2 terhadap Y & $0,652 \times 0,152$ & 0,0991 \\
\hline
\end{tabular}

Sumber : Diolah peneliti (2021)

Gambar.2 Pola Intervening

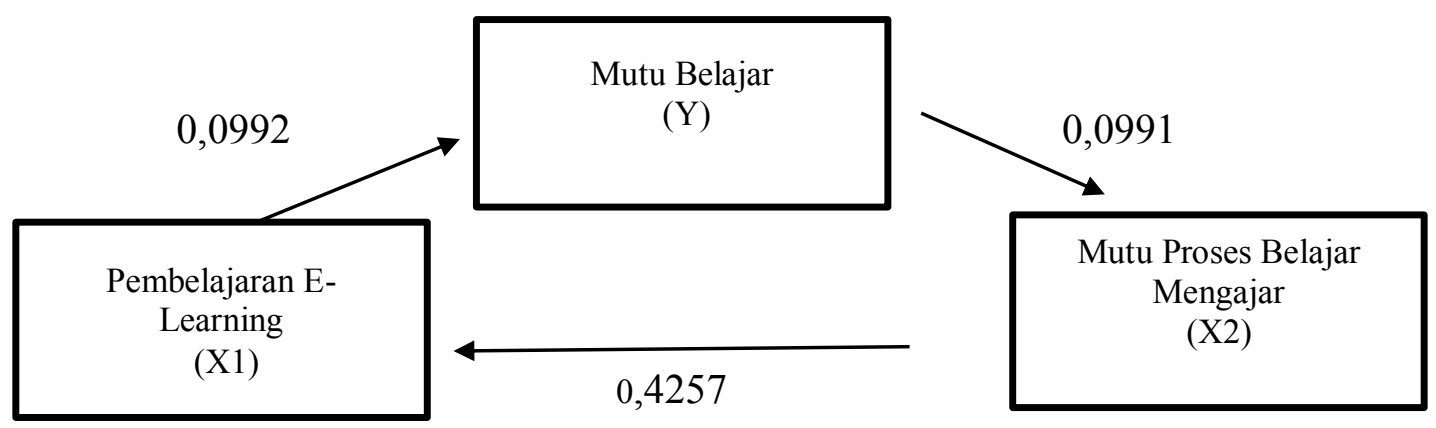

Sumber: Diolah peneliti (2021)

Dari hasil sajian olahn data diperoleh penjelasan tentang hasil koreksi melalui aplikasi spss yang lebih mendalam mengenai output dari penelitian ini. Dari penjelasan diatas telah dikatakan bahwa adanya pengaruh yang sangat signifikan pada setiap variabel independen kepada variabel dependen yang dipengaruhi langsung dari variabel intervening. Dalam menghitung pengaruh secara langsung dan tidak langsung dapat diolah melalui hasil nilai standardized coefficients regresi pada setiap variabel independen terhadap variabel dependen.

\section{Pengaruh pembelajaran e-learning terhadap mutu belajar}

Dari olahan data penelitian maka hasilnya dapat dinyatakan bahwa pembelajaran yang dilakukan secara e-earning yang berbasis zoom meeting ini memiliki hasil yang positif serta bersignifikan pada mutu belajar mahasiswa pendidikan akuntansi universitas negeri surabaya. Dari hasil uji secara statistik dapat diambil angka koefisien jalur sebesar 0,653 dan berada pada tingkatan signifikan $=0,05$ dan signifikan tabel sebesar 000. Yang dapat disimpulkan dari penemuan olahan statisik ini yaitu dapat dikatakan bahwa pembelajaran e-learning memiliki pengaruh secara langsung serta bersignifikan terhadap variabel mutu belajar yaitu 0,653 atau $65,3 \%$.

Yang artinya, para mahsiswa dapat menyerap ilmu dengan baik dan maksimal dengan melalui media pembelajaran e-learning yang berbasis zoom meeting. Mereka mendapatkan pembelajaran serta tugas maupun diskusi yang sesuai dengan rencana pembelajaran semester. Dan dosen sangat baik dalam menyampaikan setiap materi perbankan kepada mahsiswa. Oleh karena itu dengan dimaksimalkannya pembelajaran e-learning berbasis zoom meeting ini dapat meningkatkan mutu belajar mahsiswa. Hasil ini sesuai dengan penelitian yang lebih dahulu 
dilakukan oleh yang juga memiliki hasil signifikan bahwa zoom meeting merupakan pilihan yang tepat yang dapat digunakan dalam pembelajaran jarak jauh dan mempengaruhi kualitas serta mutu belajar mahasiswa. Seluruh komponen serta indikator pada variabel mutu belajar menurut (Prasetya \& Harjanto, 2020) yaitu, relevansi pembelajaran, daya tarik, efektifitas, efisiensi dan produkstifitas. Ini dapat dilakukan secara baik dan maksimal pada pembelajaran mahasiswa pendidikan akuntansi dan dapat didukung melalui media elektronik yang berbasis zoom meeting.

\section{Pengaruh langsung mutu belajar terhadap mutu proses belajar mengajar}

Penelitian ini mendapatkan hasil yang positif dan memiliki pengaruh secara langsung dari variabel mutu belajar terhadap variabel mutu proses belajar belajar. Hasil uji statistik yang memiliki angka koefisien jalur sebesar 0,652 dan pada uji statistik signifikan pada tingkatan $=0,05$ dan signifikan tabel yang berarti nilai tersebut lebih rendah atau sama dengan 0,05 $(0,000>0,05)$ dapat disimpulkan bahwa adanya pengaruh secara langsung dengan nilai yang signifikan anatara mutu belajar terhadap mutu proses belajar mengajar sebesar $65,2 \%$.

Yang berarti semakin meningkatkan mutu belajar mahasiswa maka itu juga didorong oleh baiknya mutu proses belajar mengajar didalam pembelajaran. Hasil dari olahan penelitian ini dapat menarik kesimpulan bahwa dalam pembelajaran secara e-learning yang berbasis zoom meeting ini, dosen sangat memaksimalkan agar mahasiswa ikut serta dalam diskusi dalam kelas. Dengan memberikan keterlibatan mahasiswa dalam menentukan keputusan dalam kelas agar jalannya proses pembelajaran e-learning ini dapat berjalan baik supaya tujuan belajar mengajar dapat tercapai. Keterlibatan secara aktif oleh dosen melalui online ini juga dapat menetukan mutu belajar mengajar dalam pembelajaran. Dan mahasiswa menjawab bahwa dosen memberikan kesertaraan pada setiap mahasiswa dalam berpartisipasi dan dapat menghormati hak mahasiswa yang dapat menimbulkan problem solving dan pemikiran yang kritis bagi mahasiswa. Hal ini sesuai dengan teori yang diungkapkan oleh (McCombs, 2000) yang menyatakan bahwa dalam pembelajaran secara e-learning akan memicu hasil belajar yang berbeda dari setiap mahasiswa, maka diperlukannya mutu proses belajar mengajar yang berkualitas dari pihak dosen dan keterlibatan mahasiswa dalam mengikuti perkuliahan online. Dosen memberikan variasi pembelajaran dan mahasiswa mengikuti proses belajar mengajar dengan baik, maka akan menciptakan hasil yang baik dari mutu belajar mahasiswa dan dukungan pembelajaran e-learning berbasis zoom meeting serta meningkatankan mutu proses belajar mengajar.

\section{Pengaruh pembelajaran e-learning terhadap mutu belajar melalui mutu proses belajar mengajar}

Dari pengolahan data yang telah dianalisis maka terdapat pengaruh secara langsung pada pembelajaran e-learning terhadap mutu belajar melalui mutu proses belajar mengajar. Seperti hasil statistik melalui regresi dari tabel coefficient substruktural dapat diambil nilai signifikan dari variabel pembelajaran e-learning yaitu sebesar 0,0178 karena nilai signifikan lebih kecil dari $0,05(0,0178<0,05)$ dan nilai signifikan variabel mutu belajar ialah 0,037 juga lebih kecil dari 0,05 dan dapat disimpulkan bahwa terdapat pengaruh secara tidak langsung dari pembelajaran e-learning terhadap mutu belajar melalui mutu proses belajar mengajar.

Artinya, dalam pembelajaran e-learning yang berbasis zoom meeting pada mahasiswa pendidikan akuntansi ini berjalan lancar dan baik dari segi e-learning. Namun tidak memungkiri masih terdapat beberapa faktor lain yang belum diteliti yang dapat mempengaruhi 
mutu proses belajar mengajar melalui pembelajaran e-learning ini. Meski berjalan dengan baik, namun pembelajaran e-learning ini banyak memiliki kelemahan. Seperti jangkauan dan jaringan setiap daerah yang berbeda-beda. Dengan begini hasil dari mutu belajar mahasiswa akan berbeda satu sama lain. (Dabbagh, 2012) menyebutkan bahwa terdapat beberapa ciri yang bisa dikategorikan dalam perilaku mahasiswa untuk mengikuti dan menjalankan pembelajaran e-learning yaitu, spirit belajar, literasi teknologi, memiliki kemampuan interpersonal, kolaborasi dan belajar mandiri. Menurut (Dabbagh, 2012) ini bahwa mahasiswa akan berhasil mengikuti pembelajaran secara e-learning apabila memenuhi kelima komponen tersebut untuk menunjang mutu belajar mereka. Namun hasil dari penelitian ini menyatakan bahwa pembelajaran e-learning memiliki pengaruh secara tidak langsung terhadap mutu belajar melalui mutu proses belajar mengajar. Sehingga menimbulkan kemungkinan diluar faktor pembelajaran e-learning yang dapat mempengaruhi mutu belajar mahasiswa.

Variabel pembelajaran e-learning ini dapat mewujudukan mutu belajar yang baik apabila didukung dengan mutu proses belajar mengajar yang maksimal pula. Dalam pembelajaran yang dialami mahasiswa pendidikan akuntansi angkatan 2018 ini melalui pembelajaran e-learning pada mata kuliah perbankan syariah, mereka dapat menerima materi secara baik dari dosen dengan materi dan tugas yang sesuai. Maksimalnya dosen dalam memberikan pengajaran ini dapat meningkatan mutu proses belajar mengajar yang berpengaruh pada hasil mutu belajar mahasiswa. Mahasiswa merasa jelas dan kooperatif dalam mengikuti pembelajaran e-learning ini. Pembelajaran melalui zoom meeting ini pilihan yang tepat untuk diterapkan dalam pembelajaran pada masa pandemi covid-19 ini yang mengaharuskan melakukan pembelajaran jarak jauh.

\section{Kesimpulan dan Saran}

Dari keseluruhan penjelasan dapat disimpulkan bahwa hasil dari penelitian ini menyatakan terdapat pengaruh yang positif serta bersignifikan pada pembelajaran e-learning berbasis zoom meeting terhadap mutu belajar pada mahasiswa pendidikan akuntansi Univesitas Negeri Surabaya angkatan 2018 pada mata kuliah perbankan syariah. Artinya, pembelajaran e-learning berbasis zoom meeting ini berkontribusi dalam meningkatkan mutu belajar mahasiswa secara langsung dan dapat memperbaiki kualitas mahasiswa Universitas Negeri Surabaya. Karena pembelajaran e-learning berbasis zoom meeting ini tetap dapat membantu dosen dalam menyampaikan materi pembelajaran secara maksimal. Dari hasil uji statistik yang akurat dan valid menunjukkan secara langsung pembelajaran e-learning terhadap mutu belajar. Kesimpulan dari pengolahan data statistik tersebut dapat dinyatakan apabila pembelajaran e-learning berbasis zoom meeting ini dapat berpengaruh secara langsung dengan angka yang signifikan pada mutu belajar. untuk Hasil penelitian pada variabel pembelajaran e-learning berbasis zoom meeting yang secara statistik signifikan. Yang artinya pembelajaran e-learning ini berkontribusi serta berdampak secara langsung terhadap mutu proses belajar mengajar dengan signifikan. Serta pada penelitian uji statistik mutu belajar dan mutu proses belajar mengajar menyatakan bahwa mutu belajar juga memiliki pengaruh secara signifikan. Penelitian ini membuktikan bahwa para mahasiswa tetap dapat belajar dan menerima materi pembelajaran perbankan syariah secara maksimal, dengan dukungan dosen yang baik dan media belajar berbasis e-learning yang maksimal. Dengan demikian pembelajaran e-learning ini dapat meningkatkan mutu belajar mahasiswa melalui full intervening dengan variabel mutu proses belajar mengajar. Dan dari gambaran pola intervening maka dapat diartikan bahwa hasil dari penelitian ini full intervening, yaitu 
mendukung mediasi mutu proses belajar mengajar sebagai pengaruh mutu belajar pada mahasiswa pendidikan akuntansi angkatan 2018.

Dari dilakukannya penelitian tersebut adapun beberapa hasil yang ditemui dari keseluruhan kajian dari penelitian ini, maka peneliti dapat memberikan saran sebagai berikut: 1).Bagi peneliti selanjutnya yang ingin melanjutkan penelitian ini, hendak mencari variabel lain yang dapat berkontribusi dan berpengaruh pada mutu belajar, seperti: sarana prasarana belajar, pendidikan orangtua, kesehatan mental dan variabel lain yang dapat berpengaruh pada mutu belajar mahasiswa agar penelitian ini dapat lebih sempurna dan dapat memperluas wawasan. 2).Bagi para dosen yang mengajar secara e-learning yang berbasis zoom meeting, dapat mengembangkan beberapa varian dalam proses pembelajaran.

\section{Daftar Pustaka}

Aziz, A. (2015). Peningkatan Mutu Pendidikan. Jurnal Studi Islam Peningkatan Mutu, 10(2), $1-14$.

Dabbagh, N. (2012). Learner Characteristics and Online Learning. SpringerReference, 7, $217-$ 226. https://doi.org/10.1007/springerreference_302098

Daniati, D., Ismanto, B., \& Luhsasi, D. I. (2020). Upaya Peningkatan Motivasi dan Hasil Belajar Mahasiswa dengan Penerapan Model Pembelajaran E-Learning Berbasis Google Classroom pada Masa Pandemi Covid-19. Jurnal Kependidikan: Jurnal Hasil Penelitian Dan Kajian Kepustakaan Di Bidang Pendidikan, Pengajaran Dan Pembelajaran, 6(3), 601. https://doi.org/10.33394/jk.v6i3.2642

Dimyati, \& Mudjiono. (2006). Belajar dan Pembelajaran. Rineka Cipta.

El-Sofany, H. F., \& El-Haggar, N. (2020). The effectiveness of using mobile learning techniques to improve learning outcomes in higher education. International Journal of Interactive Mobile Technologies, 14(8), 4-18. https://doi.org/10.3991/IJIM.V14I08.13125

Elyas, A. H. (2018). Penggunaan model pembelajaran e-learning dalam meningkatkan kualitas pembelajaran. Jurnal Warta, 56(04), 1-11.

http://jurnal.dharmawangsa.ac.id/index.php/juwarta/article/view/4

Haqien, D., \& Rahman, A. A. (2020). Pemanfaatan Zoom Meeting untuk Proses Pembelajaran pada Masa Pandemi Covid-19. SAP (Susunan Artikel Pendidikan), 5(1). https://doi.org/10.30998/sap.v5i1.6511

Imam, G. (2013). Aplikasi Analisis Multivariate dengan Program SPSS. Badan Penerbit BPFE.

Karwati, E. (2014). Pengaruh Pembelajaran Elektronik (E-Learning) terhadap Mutu Belajar Mahasiswa. Jurnal Penelitian Komunikasi, 17(1), 41-54. 
https://doi.org/10.20422/jpk.v17i1.5

Kirkman, S., Coughlin, K., \& Kromrey, J. (2007). Factors Influencing Development of SelfDirected Learning in a Higher Education Environment. International Journal of SelfDirected Learning, 4(1), 39-52.

Koran, J. K. C. (2015). Aplikasi E-Learning dalam Pengajaran dan Pembelajaran Di SekolahSekolah Malaysia. Elearning.

MARINI, A. (2017). Character Building Through Teaching Learning Process: Lesson in Indonesia. PONTE International Scientific Researchs Journal, 73(5), 177-182. https://doi.org/10.21506/j.ponte.2017.5.43

McCombs, B. L. (2000). Assessing the role of educational technology in the teaching and learning process: A learner-centered perspective. The Secretary's Conference on Educational Technology, 2000: Measuring Impacts and Shaping the Future, 1-17. https://files.eric.ed.gov/fulltext/ED452830.pdf

Meliyani, M., Supriyanto, S., \& Rahmattullah, M. (2019). Pengaruh Pemanfaatan Simari Sebagai Implementasi Pembelajaran Berbasis E-Learning Terhadap Hasil Belajar Mahasiswa Prodi Pendidikan Ekonomi. Jurnal Pendidikan Ilmu Sosial, 29(1), 1-8. https://doi.org/10.23917/jpis.v29i1.8232

Prasetya, T. A., \& Harjanto, C. T. (2020). Pengaruh mutu pembelajaran online dan tingkat kepuasan mahasiswa terhadap hasil belajar saat pandemi Covid19. Pendidikan Teknologi Dan Kejuruan, 17(2), 188-197.

Rusman, -. (2017). The Development of an E-Learning-Based Learning Service for MKDP Curriculum and Learning at the Indonesia University of Education. International Research Journal of Engineering, IT \& Scientific Research, 7(31), 83-87. https://doi.org/10.21744/irjeis.v3i2.410

Subhi, I. (2020). Urgensi Upaya Menjaga Mutu Pembelajaran di Tengah Pandemi Covid 19. Edification Journal, 3(1), 35-56. https://doi.org/10.37092/ej.v3i1.213

Sugiyono. (2016). Metode Penelitian Kuantitatif, Kualitatif, dan RnD. Alfabeta.

Suharyanto, \& Mailangkay, adele B. L. (2016). Penerapan E-Learning Sebagai Alat Bantu Mengajar Dalam Dunia Pendidikan. Jurnal Ilmiah Widya, 3, 17-21. https://doi.org/10.1016/j.neubiorev.2016.02.001

Suhirman. (2012). Pengaruh Biaya Pendidikan Terhadap Hasil Belajar Melalui Proses Belajar Mengajar Di Sma Negeri Se-Kabupaten Rembang Tahun 2011. The Journal of Economic Education, 1(2), 117-122.

Suliyanto. (2017). Pelatihan Metode Pelatihan Kuantitatif. Journal of Chemical Information and Modeling, 5(2), 223-232. 
Sumardi, L., Rohman, A., \& Wahyudiati, D. (2020). Does the teaching and learning process in primary schools correspond to the characteristics of the 21 st century learning?

International Journal of Instruction, 13(3), 357-370.

https://doi.org/10.29333/iji.2020.13325a 